\title{
The Bridge
}

2006

Conference Opening Remarks

Lene Balleby

Follow this and additional works at: https://scholarsarchive.byu.edu/thebridge

Part of the European History Commons, European Languages and Societies Commons, and the Regional Sociology Commons

\section{Recommended Citation}

Balleby, Lene (2006) "Conference Opening Remarks," The Bridge: Vol. 29 : No. 2 , Article 8.

Available at: https://scholarsarchive.byu.edu/thebridge/vol29/iss2/8

This Article is brought to you for free and open access by BYU ScholarsArchive. It has been accepted for inclusion in The Bridge by an authorized editor of BYU ScholarsArchive. For more information, please contact scholarsarchive@byu.edu, ellen_amatangelo@byu.edu. 


\section{Conference Opening Remarks}

by Lene Balleby

When I first heard about this year's conference, it was being launched as a celebration and recognition of two of Denmark's most famous sons: Hans Christian Andersen and Søren Kirkegaard. But looking at the extensive program for the upcoming days, it is clear that this program is also meant to present a much wider picture of the richness and scope of Danish culture and that it will indeed live up to its title: "Danish Culture, Past and Present."

Tonight I would like to start off with the present and some areas of new relations where Denmark has also lately experienced extensive media coverage. It is always well and good to remember and revere the old, established icons of culture, but it is also good to see the tremendous American interest in the new and coming arts and artists. These must be nurtured and helped along so that Denmark can continue to inspire and enlighten through great art and cultural events. For a small country like Denmark it is absolutely vital that we keep giving priority to these "softer" values and keep creating the right environment for artists to work and thrive in. It is vital not only in order for people like you to have new and exciting subjects to work with, show off, and spread the word about, but also because it is an integral part of keeping our roots healthy and strong for future generations.

Denmark has so much to offer in the cultural fields today and I would like to briefly focus on the world of design. The New York Times two weeks ago proclaimed Copenhagen to be the European Hot Spot for design. I can personally vouch for the fact that Danish industrial design is doing better than ever. With the recent scoop that resulted in Danish furniture exclusively adorning the reopened Museum Of Modern Art in New York and a major exhibit in Washington, D.C. in 2004 that featured several Danish women designers, there really is an almost unprecedented focus on Danish design in the United States at this time. This fall, Copenhagen is 
also the host city of INDEX 2005-a world event for design and innovation set to take place every four years in Copenhagen. This is the first year of this event and yet more proof of just how thriving a cultural industry Danish design is.

Speaking of what I like to term "cultural industries," I'd also like to draw your attention to another area where Denmark is making great strides on the international stage, and that is within fashion. Danish fashion is rapidly becoming a major trendsetter and is on the absolute forefront when it comes to mixing the "artistic" and innovative with what is also commercially viable.

Other vibrant areas of Danish culture include the more classical branches such as film, dance, and music, but in present company there is probably not much I could tell you about these "flagship" areas. Allow me, though, to briefly mention the brand new opera house in Copenhagen that has garnered rave reviews throughout the world for both its architecture and its superb performances. In connection with this new opera, it is worth mentioning that the famous Danish composer Poul Ruders was recently honored by the extremely prestigious Koussevitzky Music Foundation with a commission for his Symphony No. 3, and the work likely will have its world premier at this unique Copenhagen venue. The Koussevitsky Foundation works under the auspices of the United States Library of Congress and is thus right at the very heart of one of the most important cultural institutions in this great country.

So there is much to be proud of and to look forward to in coming years, and I hope that Denmark can keep counting on people like you, and on your enthusiasm, to keep spreading the word about Denmark and all her wonderful qualities!

But as with most things in life there is always room for improvement and when it comes to spreading the word about Denmark and Danish arts and culture here in the United States, more can always be done. Since we are all gathered here, I would like to seize this opportunity to direct an appeal to you.

At the present time, Denmark has two official representatives, I and my colleague in New York, Irene Krarup, who, on a daily basis, work with promoting Danish culture here in the United States. Needless to say, there is only so much we can do, and this is where 
my appeal to you comes in. Irene and I would like to organize a much more efficient and strong cultural network. Of course we both already have a network to draw on, but it could be so much stronger if it had even more representation from around the country. When we are approached by Danish artists who want to perform here in the United States, we often can't set up anything for them in either New York or Washington, and we have to tell them that there's nothing we can do for them. But just because an event can't happen on the east coast shouldn't mean that it can't happen somewhere else!

What I would like is-in the course of this conference-is for anyone interested in joining a list of "cultural frontrunners" to get in touch with either me or Irene and give us your contact information so that we can send information on to you about some of these adventurous and capable artists. This year's many Hans Christian Andersen events have proved to me that so much can be done by people such as you - the grassroots-out across the country. Because you are the people who have the knowledge about your communities and know precisely how and what is possible in your neck of the woods.

I hope this message hasn't fallen too much outside the norm for opening remarks. I simply couldn't let this glorious opportunity to "enlist" some cultural foot soldiers slip by! Let me now thank you for all the work you are already doing and for the dedication you show when it comes to maintaining and nurturing vital and vibrant links - both past and present-to Denmark. Thanks to all of you who every day, year in and year out, help citizens of the United States learn more about Denmark and thereby help to strengthen the already strong ties between our two countries. May the DanishAmerican relations continue to flourish for many years to come.

I wish you all an enjoyable conference. 